\title{
大変形，大変位を伴うテザードシステムの 姿勢制御下における動的応答*
}

\author{
竹原 昭一郎*1, 嘩 道 佳 明*1 \\ 能 見公 博*2, 曽我部潔*1
}

\section{Dynamic Response of a Tethered System with Large Deformation and Large Displacement under Attitude Control}

\author{
Shoichiro TAKEHARA*3, Yoshiaki TERUMICHI, \\ Masahiro NOHMI and Kiyoshi SOGABE \\ ${ }^{* 3}$ Department of Mechanical Engineering, Sophia University, \\ 7-1 Kioi-cho, Chiyoda-ku, Tokyo, 102-8554 Japan
}

\begin{abstract}
In this paper, we discuss the dynamic response of a system consisting of a very flexible body and rigid bodies at its end under attitude control to the end body. A tethered subsatellite in space is known as an example of this system. Two mathematical models for a planer motion of a flexible body are considered using FEM and Absolute Nodal Coordinate Formulation. In A.N.C Formulation, it is easy to describe the motion of the flexible body with large deformation, rotation and translation displacement. We attempt to control the attitude of the end body using a reaction wheel. The control technique consists of an attitude control by the reaction wheel and a control by the reaction wheel with the joint torque control to cancel accumulation of angular momentum. First, eigenvalue analysis is carried out where control gain changes. Second, the motion under controlled system is discussed its free vibration, comparing the motions of FEM model and A.N.C one. It is pointed out that the axial stress in the tether plays an important role as constraint force at the joint between the tether and the rigid body. Furthermore we treat large deformation, large displacement problem, where the end of the flexible body moves horizontally. We confirm the interaction between flexible body with large deformation and rigid body under the attitude control and clarify its mechanism.
\end{abstract}

Key Words: Multibody Dynamics, Flexible Body, Large Deformation and Displacement, Rigid Body, Coupled Motion, Attitude Control

\footnotetext{
1. 緒

テザードシステムは軽量，収納性のよさ等の利点 を備えており，宇宙空間，海中などの特殊環境におい てその利用が期待されている(い)、このシステムは母 船につながれたテザー（ワイヤーロープやひも）とそ れに連結された先端機で構成されており, テザ一先端 機に何らかの作業をさせる場合，その姿勢制御が重要 となる. さらに，上述の特殊環境では，テザーに作用 する張力が微小となり, 大変形, 大変位を伴う場合が 想定される. しかし，テザー先端機が複数剛体て構成 されているような系では，テザーの運動と先端幾の運 動が干渉し, その挙動は複雑になることが予想される. このような状態において精度の高い姿勢制御を行うに

* 原稿受付 2003 年 3 月 20 日.

*1 正員, 上智大学理工学部( $102-8554$ 東京都千代田区紀尾 井町 7-1).

*2 正員, 香川大学工学部 ( 861-0396 高松市林町 2217-20).

E-mail : s-takeha@ sophia.ac.jp
}

は，大変形，大変位問題に対応したテザーと先端機の 連成運動を考慮する必要がある.

しかし，従来のこの種の系に対する研究では，弦 と集中質量系を扱った解析例的は見られるものの， 柔軟体と剛体系との連成運動については十分な検討が なされていないようである. さらに, この系をマルチ ボディシステムとして捉えるとき，柔軟体と剛体の混 在系, 超柔軟体の大変形, 大変位問題, 制御系之の 連成，先端剛体の姿勢制御下における動特性の変化な どの工学的に注目すべき特性を備えている.

本報では，著者の一部による既報わと同様に，この ようなシステムを柔軟体・剛体系としてモデル化する. 既報では，先端幾の制御に関してはリアクションホイ 一ルを用いた制御法，またリアクションホイールに角 運動量が蓄積されてしまうという問題があるために, 先端機に装備した剛体によりテザー連結点を操作する ことによって角運動量を排出する制御法を提案した. 
ここでは, この系の運動解析をテザーの大変形, 大変位問題に抁張し, 姿势制御下における系の動的応 答を以下の手順により検討する. まず, テザードシス テムの基磷的な動特性を把握するために，テザーに関 して線形モデルを用い解析的な固有值解析を行い，制 御入力ゲインの変化に対する系の固有值の変化につい て調べる. 次にテザーに関して大変形，大変位問題に 対応した定式化を行い，自由振動下における系の 運動について数值シミュレーションを行い，固有值解 析から得た知見を確認する. また, 線形モデルの運動 と比較することにより制御下における大変形の影響を 検討する. さらに, 大変形, 大変位を与えた数值シミ ユレーションを行い，先端岡体の姿勢制御下における テザーと剛体の連成運動のメカニズムについて検討す る.

\section{2. 解析モデルと剛体系の姿勢制御}

2.1 解析モデル 図1に解析モデルを示す。こ こでは，テザーを上端を固定された柔軟体（長さ $l$, “密度 $\rho$, 断面積 $A$ ）とし, 先端機は複数の剛体より 構成されているものとする. 本報では, 複数の剛体系 は，関節を表現するために必要である最小の二つの剛 体（長さ $2 d_{l, 2}$, 質量 $m_{l, 2}$, 重心回りの慣性モーメント $\mathrm{I}_{1,2}$ ）により構成されている. 剛体 1 はテザーに連結 され，剛体 1 と剛体 2 は剛性を無視できる回転関節に より連結されている. また, 必要に応じて岡㤓間の回 転関節には任意のトルクが加えられるものとする. さ らに剛体2にはリアクションホイール（質量 $m_{w}$, 慣 性モーメント $I_{w}$ ）が取り付けられている. 本報では, 弦と剛体系の相互作用の制御効果に対する基本的な影 響を検討するために平面運動のみを考える.

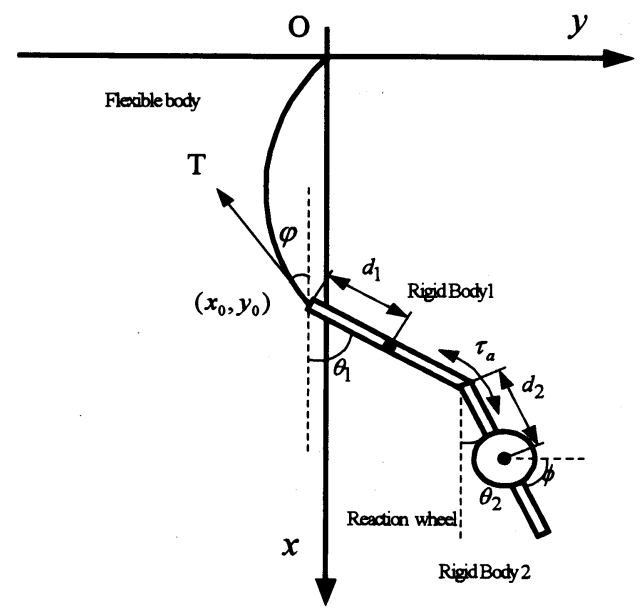

Fig.l Analytical model of tethered system
2.2 䣓体系の制御法 本章では, 著者の一部に よる既報》と同様にテザ一先端機の姿勢制御に対して, リアクションホイールによる制御法, そしてリアクシ ヨンホイールに蓄積する角運動量を剛体間の関節トル クを用いることによって排出することを考える. 本報 では以後この制御法を角運動量抑制制御と呼ぶことと する.

2.21 リアクションホイール制卸まず, リア クションホイールを用いた先端機の姿勢制御を考える. リアクションホイールは剛体 2 の重心位置に取り付け るとする. リアクションホイールに加えるトルク $I_{w} \ddot{\phi}$ はPD制御を用いて以下のように与える.

$$
\begin{aligned}
& I_{w} \ddot{\phi}=I_{w} k_{p \theta}\left(\theta_{2}-\theta_{c}\right)+I_{w} k_{d \theta} \frac{d}{d t}\left(\theta_{2}-\theta_{c}\right) \quad(1) \\
& \text { この式において, } \theta_{c} \text { は目標角であり } k_{p \theta}, k_{d \theta} \text { は制 }
\end{aligned}
$$
御入力ゲインである. 本報では, 目標角 $\theta_{c}=0$, $k_{p \theta}=k_{d \theta}$ として式(1)を以下のように扱うものとする.

$$
I_{w} \ddot{\phi}=I_{w} k_{w}\left(\theta_{2}+\dot{\theta}_{2}\right)
$$

ここで， $k_{w}$ はリアクションホイール制御入カゲイン である.

2.2 角運動量抑制制御 ここでは, リアクシ ヨンホイールに蓄積された角運動量を排出するために, 関節トルク制御を用いる. この制御法では関節トルク によって柔軟体と剛体の結合点が動き，柔軟体による 張力がリアクションホイール蓄積角運動量を減少させ る回転力を発生するため, リアクションホイールの角 運動量が排出される. 関節トルクはリアクションホイ 一ルに対する $\mathrm{PD}$ 制御により以下のように求める.つ まり, 式(2)で得られたリアクションホイール角加速 度と, 角加速度を数值積分することによって求めた角 速度とのフィードフォワード制御となる. このときも 前節と同様の目的角ならびに制御入力ゲインの関係を 用いている.

$$
\tau_{a}=I_{w} k_{a}(\dot{\phi}+\ddot{\phi})
$$

ここで $k_{a}$ は角運動量抑制制御における関節トルク入 カゲインである.

\section{3. 定式化}

3.1 線形モデルの定式化 本節では, 著者の 一部による既報劣と同様に，弦と見なしたテザーと剛 体系の運動の連結点の座標 $\left(x_{0}, y_{0}\right)$, および各剛体の 鉛直軸からの角度 $\theta_{1} ， \theta_{2}$ を状態量として, これらの 状態ベクトルを と表す.

$$
\mathbf{q}=\left[\begin{array}{llll}
x_{0} & y_{0} & \theta_{1} & \theta_{2}
\end{array}\right]
$$

これにより運動方程式は となる. 
ここで， $\mathbf{I}_{\mathbf{m}}$ は慣性行列， $\mathbf{h}$ は遠心力, コリオリカ, 重力を表す． $\mathbf{N}$ は張力による外力項， $\mathbf{u}$ は制御入力 項であり，以下のように表される.

$$
\mathbf{N}=\left[\begin{array}{c}
-T \cos \varphi \\
-T \sin \varphi \\
0 \\
0
\end{array}\right], \quad \mathbf{u}=\left[\begin{array}{c}
0 \\
0 \\
\tau_{a} \\
-I_{w} \ddot{\phi}-\tau_{a}
\end{array}\right]
$$

テザーの運動は有限要素法により長さ $l_{e}$ の $\mathrm{n}$ 個の 線要素に離散化し, 各節点ごとの座標系 $x-y$ に対す る $\mathrm{y}$ 方向の変位量 $\boldsymbol{w}_{i}$ に関する定式化を行う. テザー 下端の要素に関する方程式は, 次のようになる.

$$
\frac{\rho A l_{e}}{6} \mathbf{M} \ddot{\mathbf{w}}+\frac{T_{e}}{l_{e}} \mathbf{K w}=\mathbf{T}
$$

w は横方向変位 $w_{i}(i=1,2, \cdots, n+1)$ から構成されるべ クトル， $\mathbf{M}$ おび $\mathbf{K}$ は慣性マトリクスおよひ㓮性マ トリクス， $\mathbf{T}$ は各要素に働く張力を表すべクトルで あり，各要素で一定である. テザー下端の横方向変位 $w_{n+1}$ は連結点の横変位であるので $w_{n+1}=y_{0}$ であるこ とを考慮して, 式(6)のテザー下端 $w_{n+1}$ に関する方程 式，およひ式(5)の剛体上端の水平方向変位に関する 方程式を合成することにより，テザーと剛体系の連結 点すなわちテザー下端の境界条件式を得る.

$$
\begin{aligned}
& \left(m_{1}+m_{2}+m_{w}+\frac{\rho A l_{e}}{3}\right) \ddot{w}_{n+1}+\frac{\rho A l_{e}}{6} \ddot{w}_{n}+\frac{T}{l_{e}}\left(w_{n+1}-w_{n}\right) \\
& +\left\{d_{1} m_{1}+2 d_{1}\left(m_{2}+m_{w}\right)\right\}\left(\cos \theta_{1} \cdot \ddot{\theta}_{1}-\dot{\theta}_{1}^{2} \sin \theta_{1}\right) \\
& \quad-d_{2}\left(m_{2}+m_{w}\right)\left(\sin \theta_{2} \cdot \ddot{\theta}_{2}+\dot{\theta}_{2}^{2} \cos \theta_{2}\right)=0 \\
& \text { テザーと剛体の連結点の縦変位 } x_{0} \text { は } \\
& x_{0}=\sum_{i=1}^{n} \frac{n}{2 l}\left(w_{i+1}-w_{i}\right)^{2}
\end{aligned}
$$

により幾何学的に求め, 張力は式(5) の㓮体上端の水 平方向変位に関する方程式より求める.

3.2 大変形, 大変位モデルの定式化 ここで は，テザーを超柔軟体とし，既報福と同様に柔軟体 の運動を定式化する. このとき, Shabana らによって 提案された Absolute Nodal Coordinate Formulation（以 下 ANC 法) ${ }^{(8)(9)}$ を用いる. この方法は大変形, 大変位 を伴う運動を表現することができ，要素の節点座標と して要素の勾配を用いるといった特徴がある. ANC 法 では復元力は弾性エネルギより求められ, 柔軟体内部 の応力は一定でなく, 要素の伸びによって時間的に変 化する. ここでは，後に剛体系の結合を考虑すること から，ANC 法の概略を説明する．ここで， E : 縌弾性係 数, $\mathrm{A}$ : 断面積, $\rho$ :弦の密度, $\ell_{\mathrm{e}}$ : 弦の 1 要素の 長さ, $\ell$ :弦の全長とする.

図 2 に全体座標系0-XYZ内におかれた柔軟体の 1 要 素を示す，なお，本報では，柔軟体は $X-Y$ 平面上での 運動に限定する. 変形前の要素を OA とし, 変形後の
要素を 0’ A' とする. 要素上の任意点の全体座標系 での位置ベクトルは形状関数 $\mathbf{s}$ と要素節点座標ベクト ルeを用いて

$$
\mathbf{r}=\mathbf{S e}
$$

と表すことができる.

ここで, 要素節点の全体座標による節点変位は $\mathbf{e}=\left[\begin{array}{llllllll}e_{1} & e_{2} & e_{3} & e_{4} & e_{5} & e_{6} & e_{7} & e_{8}\end{array}\right]^{T} \quad(10)$ と表され, $e_{1}, e_{2}$ は点 $O^{\prime}$ における X, Y 座標, $e_{3}, e_{4}$ は 点 $O^{\prime}$ における全体座標系での要素の勾配であり， $X$, $Y$ 座標で定義される $O^{\prime}$ 点での変位の空間微分である. 同様に $e_{5}, e_{6}$ は点 $A^{\prime}$ における $X, Y$ 座標, $e_{7}, e_{8}$ は点 $A^{\prime}$ における全体座標系での要素の勾配である. また, $\mathbf{s}$ は形状関数マトリクスである.

この要素の運動エネルギは次式によって表される.

$$
\begin{aligned}
T & =\frac{1}{2} \int_{V} \rho \dot{\mathbf{r}}^{T} \dot{\mathbf{r}} d V=\frac{1}{2} \dot{\mathbf{e}}^{T} \mathbf{M}_{a} \dot{\mathbf{e}} \\
\text { ここで, } & \mathbf{M}_{a} \text { は } \\
\mathbf{M}_{a} & =\int_{V} \rho \mathbf{S} \mathbf{S} d V
\end{aligned}
$$

で定義される要素の質量マトリクスである.

次に柔軟体の弾性エネルギを導出するために, 要 素座標系を考える. 図 2 において位置ベクトル $\mathbf{r}_{0}$ は $\overrightarrow{O O}$ を示しており, $\mathbf{r}$ は $\overrightarrow{O x^{\prime}}$ を示している. 任意の点 を点0’から見たときの位置ベクトルを uとするとき，

$$
\mathbf{u}=\left[\begin{array}{l}
u_{x} \\
u_{y}
\end{array}\right]=\mathbf{r}_{\mathrm{A}}-\mathbf{r}_{0}=\left[\begin{array}{l}
\left(S_{1}-S_{10}\right) \mathbf{e} \\
\left(S_{2}-S_{20}\right) e
\end{array}\right]
$$

と定義される. $\mathbf{s}_{1}$ と $\mathbf{s}_{2}$ は要素形状関数マトリクスの 列であり， $\mathbf{s}_{10}$ と $\mathbf{S}_{20}$ は点 0 で定義された形状関数マ トリクスの列である. i を次式によって定義される単 位ベクトルとする.

$$
\mathbf{i}=\left[\begin{array}{l}
i_{x} \\
i_{y}
\end{array}\right]=\frac{\mathbf{r}_{\mathrm{A}}-\mathbf{r}_{0}}{\left|\mathbf{r}_{\mathrm{A}}-\mathbf{r}_{0}\right|}
$$

となり， $\mathrm{i}$ に直交する単位べクトル $\mathrm{j}$ は

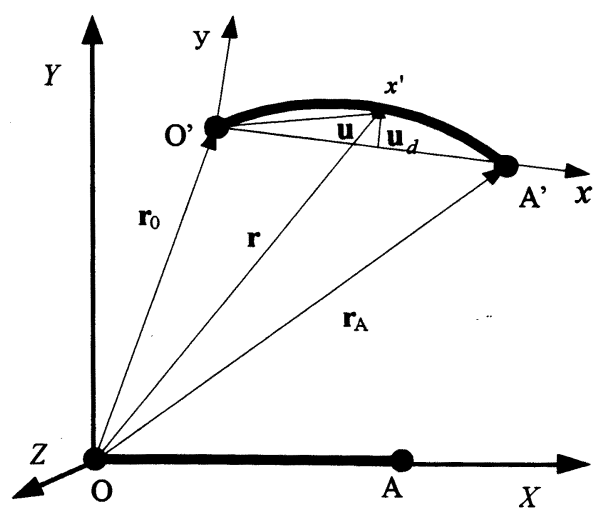

Fig.2 Deformed configuration of an element 


$$
\mathbf{j}=\left[\begin{array}{l}
j_{x} \\
j_{y}
\end{array}\right]=\mathbf{k} \times \mathbf{i}
$$

となる. ここで, $\mathbf{k}$ は $Z$ 軸方向の単位ベクトルである. このとき, 柔軟体の軸方向の変形量は, 以下のように 表される.

$$
u_{d}=\left[\begin{array}{l}
u_{t} \\
u_{t}
\end{array}\right]=\left[\begin{array}{c}
\mathbf{u}^{T} \mathbf{i}-x \\
\mathbf{u}^{r} \mathbf{j}
\end{array}\right]=\left[\begin{array}{c}
u_{x} i_{x}+u_{y} i_{y}-x \\
u_{x} j_{x}+u_{y} j_{y}
\end{array}\right]
$$

これにより，要素に貯えられるひずみエネルギ $U$ は次式のように表される.

$$
U=\frac{1}{2} \int_{0}^{t_{e}}\left(E a\left(\frac{\partial u_{l}}{\partial x}\right)^{2}+E I\left(\frac{\partial^{2} u_{t}}{\partial x^{2}}\right)^{2}\right) d x
$$

ここで, $t_{\tilde{I}}^{\sim} t_{2}$ においてポテンシャルエネルギー の変分をとると

$$
\delta U=\int_{t_{1}}^{t_{2}} \delta \mathbf{e}^{T} \mathbf{Q}_{\mathbf{k}} d t
$$

の形に書くことができる.

以上により，柔軟体の運動方程式は以下のようにな る.

$$
\mathbf{M}_{a} \ddot{\mathbf{e}}=\mathbf{Q}_{\mathbf{r}}-\mathbf{Q}_{\mathbf{k}}
$$

ここで， $\mathbf{Q}_{\mathrm{f}}$ は重力を含む外力項である.

次に, ANC 法により得られた結合点（柔軟体下端） を剛体系の上端とするような運動方程式を求める. 剛 体系の一般化座標を次式で表す。

$$
\mathbf{q}=\left[\begin{array}{llllllll}
e_{c 1} & e_{c 2} & e_{c 3} & e_{c 4} & x_{m} & y_{m} & \theta_{m} & \cdots
\end{array}\right]^{\top}(20)
$$

ここで $e_{c 1} \sim e_{c 4}$ は結合点における式(10)の $e_{s} \sim e_{8}$ に相当する. $x_{m}, y_{m}$ は剛体 $\mathrm{m} の$ 重心の座標であり, $\theta_{m}$ は各剛体の回転角度である.

仮想仕事の原理より

$$
\left[\mathbf{M}_{r} \ddot{\mathbf{q}}-\mathbf{Q}_{\mathbf{r}}\right]^{\mathbf{I}} \delta \mathbf{q}=0
$$

となる.ここで， $\mathbf{M}_{\mathrm{r}}$ は質量マトリクスである.

以後, 柔軟体下端に 2 個の剛体が取り付けられた場 合を考える. このとき式(21)の $\mathbf{Q}_{\mathbf{r}}$ は以下のように記 述される.

$$
\mathbf{Q}_{r}=\left[\begin{array}{llllllllll}
\mathrm{Q}_{c 1} & \mathrm{Q}_{e} & \mathrm{Q}_{\mathrm{s}} & \mathrm{Q}_{a} & \mathrm{mg} & 0 & \tau_{a} & \mathrm{~m}_{2} \mathrm{~g} & 0 & -I_{w} \ddot{\boldsymbol{\phi}}-\tau_{a}
\end{array}\right]^{\top}
$$

このとき, $\mathbf{Q}_{c 1}, \mathbf{Q}_{c 2}, \mathbf{Q}_{c 3}, \mathbf{Q}_{c 4}$ は柔軟体下端と剛体間に 作用する $\mathbf{Q}$, 各成分を示している.

また，系の拘束条件は次のように表現される.

$$
\Phi(\mathbf{q})=\left[\begin{array}{c}
\mathbf{p}_{1}-\mathbf{R}-\mathbf{T}_{1} \mathbf{r}_{1} \\
\mathbf{p}_{2}-\mathbf{p}_{1}-\mathbf{T}_{1} \mathbf{r}_{1}-\mathbf{T}_{2} \mathbf{r}_{2}
\end{array}\right]
$$

ここで, $\mathbf{p}_{1}=\mathbf{R}+\mathbf{T}_{1} \mathbf{r}_{1}, \quad \mathbf{p}_{2}=\mathbf{p}_{1}+\mathbf{T}_{1} \mathbf{r}_{1}+\mathbf{T}_{2} \mathbf{r}_{2}$ は剛体 1 , 2 の重心の位置べクトル,ここで $\mathbf{R}$ は前節で述べた 弦下端の節点変位, $\mathbf{r}_{1}=\left[\begin{array}{ll}d_{1} & 0\end{array}\right], \mathbf{r}_{2}=\left[\begin{array}{ll}d_{2} & 0\end{array}\right]$ は各剛体 で定義された剛体上端から重心までを結ぶ位置べクト
ル， $\mathrm{T}_{\mathrm{n}}$ は局所座標から全体座標への座標変換マトリ クスである.

ここで，ラグランジュの未定乗数を用いると，

$$
\left[\mathbf{M}_{r} \ddot{\mathbf{q}}-\mathbf{Q}\right] \delta \mathbf{q}+\lambda^{T} \Phi_{\mathbf{q}} \delta \mathbf{q}=0
$$

となるので以下の関係が成り立つ.

$$
\mathbf{M}_{r} \ddot{\mathbf{q}}+\Phi_{\mathbf{q}}{ }^{T} \lambda-\mathbf{Q}_{r}=0
$$

さらに加速度方程式は

$$
\Phi_{q} \ddot{q}=-\left(\Phi_{q} \dot{q}\right)_{q} \dot{q}-2 \Phi_{q u} \dot{q}-\Phi_{u}(=\gamma)
$$

である. 式(25) と式(26)から以下のような微分代数方 程式が得られる.

$$
\left[\begin{array}{cc}
\mathbf{M}_{r} & \Phi_{\mathbf{q}}^{\mathbf{T}} \\
\Phi_{\mathbf{q}} & \mathbf{0}
\end{array}\right]\left[\begin{array}{c}
\ddot{\mathbf{q}} \\
\lambda
\end{array}\right]=\left[\begin{array}{c}
\mathbf{Q}_{r} \\
\gamma
\end{array}\right]
$$

\section{4. 固有值解析}

本節では，先端幾の姿勢制御下におけるテザードシ ステムの基喽的な動特性について検討するために，制 御入力項を含めたテザー・剛体から成る閉ループ系の 固有值解析を行う。ここでは特に，制御入力ゲインの 変化に対する系の固有振動数变化と振動制御の収束性 の変化について議論する. 使用したパラメータを以下 に示す.

$$
\begin{aligned}
& g=9.8\left[\mathrm{~m} / \mathrm{s}^{2}\right], \quad l=10.0[\mathrm{~m}], \quad \rho A=0.03[\mathrm{~kg} / \mathrm{m}], \\
& m_{1}=1.0[\mathrm{~kg}], \quad m_{2}=1.5[\mathrm{~kg}], \quad m_{r}=0.5[\mathrm{~kg}], \\
& a_{1}=1.0[\mathrm{~m}], \quad a_{2}=2.0[\mathrm{~m}], \quad a_{r}=0.5[\mathrm{~m}], \\
& I_{1}=0.3333\left[\mathrm{kgm}^{2}\right], \quad I_{2}=2.0\left[\mathrm{kgm}^{2}\right], \\
& I_{w}=0.0625\left[\mathrm{kgm}^{2}\right]
\end{aligned}
$$

まず，各制御法において剛体 2 の角度が目標角であ る平衡点に十分制御された状態を考え，剛体系に関す る自由度を减らして理想的に制御された系の運動方程 式を表すことを考える.これより得られる固有方程式 から解析的に姿勢制御された系の固有振動数を求める (11).このように剛体 2 の角度が十分制御されたとして 剛体 1 の下端に剛体 2 とリアクションホイールの質量
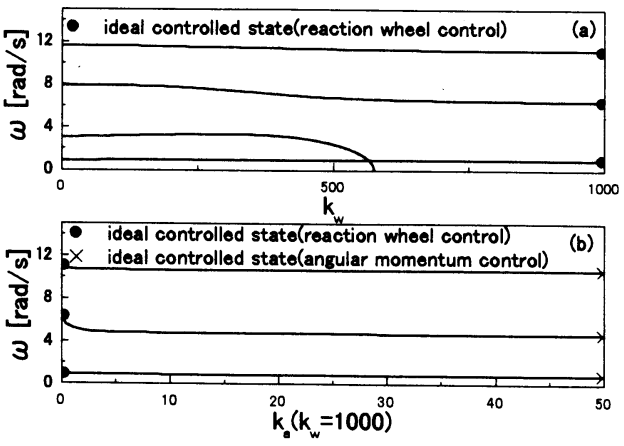

Fig. 3 Natural frequencies of the system versus control gain 
が集中している系を理想リアクションホイール制御の 系と呼ぶことにする.

次に，固有值問題の解法の一つである $\mathrm{QR}$ 法(12を用 いて系の固有値を求めた. 図 3(a), (b)にリアクション ホイール制御および角運動量抑制制御において制御入 カゲインの変化に対する系の固有振動数変化の様子を 示す. 角運動量抑制制御に関して変化させる制御入力 ゲインはリアクションホイール制御入カゲイン $k_{w}$ を 十分に大きくした場合，すなわち図3(ににおける理想 リアクションホイールの系の制御入カゲインを与えた 場合に $k_{a}$ を変化させるものとする. 図 3(a)かリアク ションホイール制御では，制御入力ゲインを大きくし ていくと一つ固有振動モードが消失する. このこと は，剛体2の角度が制御されることによって剛体系に 関する自由度が減ったことを意味する. また, 各固有 振動数が各理想制御の固有振動数に近づいていく傾向 があることがわかる．また，図 $3(\mathrm{~b})$ から角運動量抑制 制御ではゲインを変化させると理想リアクションホイ 一ル制御の系の固有振動数から理想角運動量抑制制御 の系の固有振動数へ変化していることがわかる. また, $k_{a}=10$ となる付近から固有振動数は概ね一定となる.

次に各振動の系における振動制御の収束性の速さの 違いについて検討する. 図 4にリアクションホイール 制御の系のゲインを変化させたときの固有值実部変化 の結果を示す. 図 4から制御入力の減衰項が大きくな ることにより固有值実部の值の絶対值が小さくなる.

また, 他の固有値実部の変化は両制御の系は定性的に ほぼ同傾向で 0 付近に漸近していくことがわかる. こ

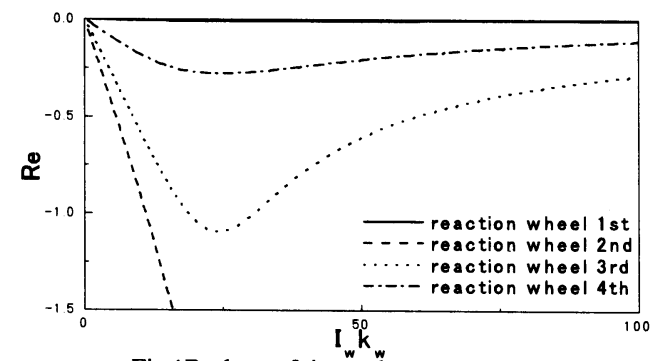

Fig.4 Real part of eigen value versuscontrol gain

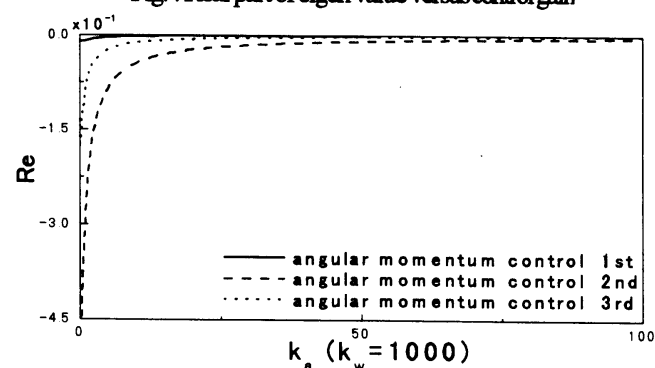

Fig.5 Real part of eigen value versus control gain
のことは制御入力トルクを大きくしていくと，姿勢制 御されることにより剛体系の振動モードが支配的な固 有振動数のうちの一つは振動制御の収束性が良くなる が，他の振動制御の収束性は悪化するということを示 している.

さらに図 5 に角運動量抑制制御の系で制御入力ゲイ ン $k_{a}$ を変化させたときの固有值実部変化の結果を示 す.この結果から， $k_{a}$ を大きくしていくと, 各モー ドの固有振動数㬰部の絶対值は急激に小さくなること がわかる. つまり， $k_{a}$ を大きくするにしたがって振 動制御の収束性は悪くなる.

\section{5. 数値シミュレーション結果}

本章では，先端機姿勢制御下におけるテザードシス テムの基本的な動特性や挙動を把握するために，まず 自由振動下において制振効果，系の挙動の特幑につい て検討し, さらに大変形，大変位問題について検討す る. 使用したパラメータは， $E=1.0 \times 10^{9}\left[\mathrm{~N} / \mathrm{m}^{2}\right]$, $a=8.0 \times 10^{-7}\left[\mathrm{~m}^{-2}\right]$ ，その他は前節と同様である. ま た, 要素分割数は $n=20$ とした.

5.1 自由振動 4 章で示した固有特性を確認す るために, 各制御の系に初期外乱を与えた場合の制 御入力項による制振効果, 系の挙動の特徴について 検討する.

ここで初期外乱として岡体 2 に角度 $\theta_{2}=\pi / 18[\mathrm{rad}]$ を 与えている. また, 制御入力ゲインは 4 章で得られ た固有值解析の結果より制振効果があると考えられ る值（ $\left.k_{w}=1000 ， k_{a}=10\right)$ を一例として採用した.
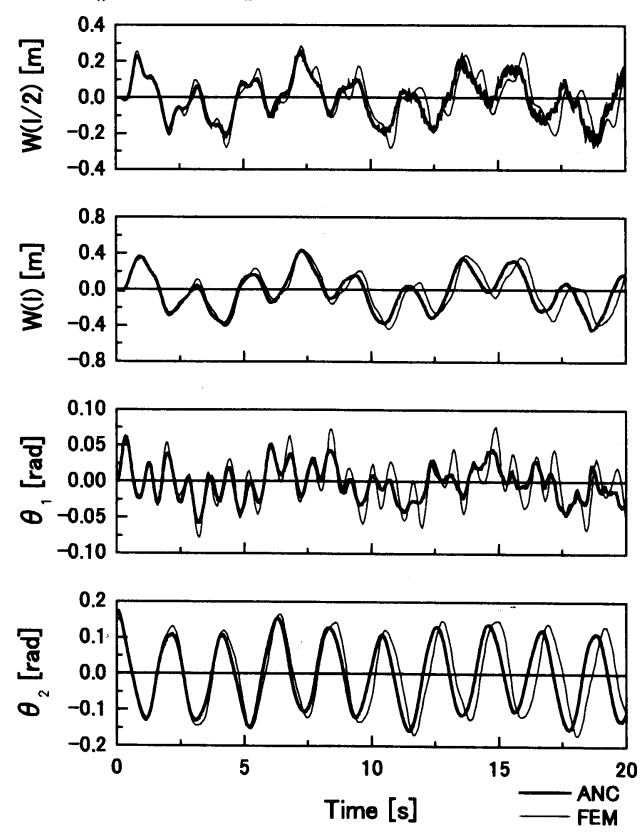

Fig.6 Time history of free vibration with no attitude control 

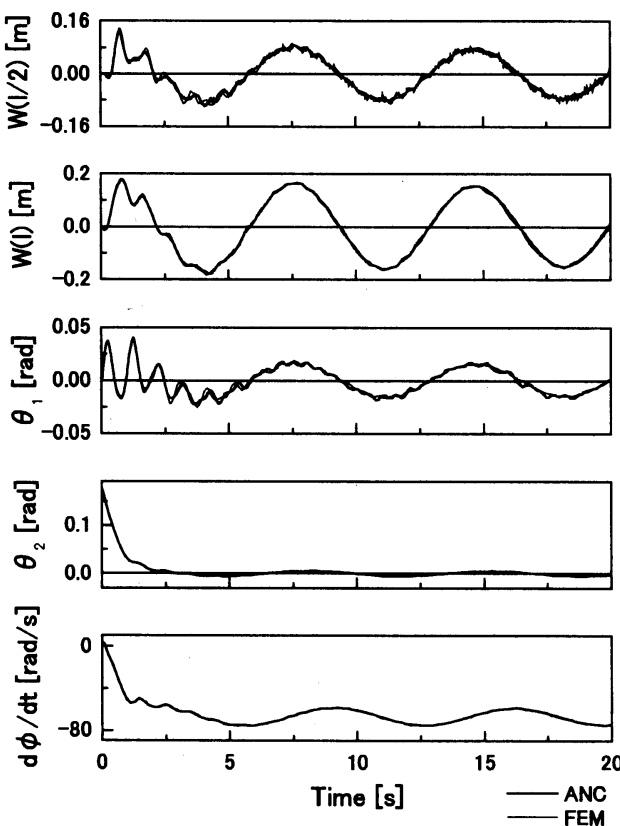

Fig.7 Time history of free vibration with the attitude control by reaction wheel control
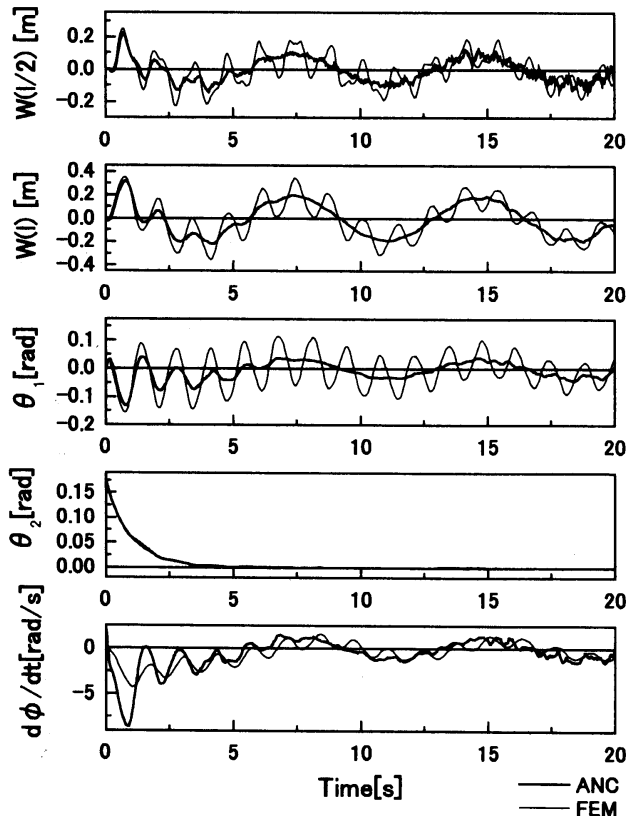

Fig. 8 Time history of free vibration with the attitude control by angular momentum control

図 6 に制御入力が無い柔軟体・2剛体系の時刻榞, 図 7, 図 8 に各制御を行った場合の時刻歷を示す. それぞれ，弦中間，下端横変位，剛体 $1 ， 2$ 角度，リ アクションホイール角速度に関する時刻歷である. 各 図中には FEM モデルと ANC モデルによる数值解析結果
の比較を行っている. これらの図より制御入力が無い 系と比較して各制御の系の剛体 2 角度に関寸る平衡点 への制振効果を確認した. また，制御された岡㤓系， 弦 1 次, 単振子の振動モードの順に振動が減衰してい くことが見られる. このとき，単振子の振動は長時間 残る.このことは図 4 の結果と一致している. 剛体 2 の振動に関しては角運動量抑制制御を用いることが制 振効果が高い，この主な要因は式(28)に示されている ように剛体 2 に関する PID 制御となり制御精度が上が るためである.

$$
-I_{w} \ddot{\phi}-\tau_{a}=-I_{w} k_{w}\left\{\left(2 k_{a}+1\right) \theta_{2}+k_{a} \int \theta_{2} d t+\left(k_{a}+1\right) \dot{\theta}_{2}\right\}
$$

FEM モデルと ANC モデルとの比較においては，図 6, 7 では両者がほぼ一致するにもかか力わらず，図 8 では 両者の振動の様相に著しい差異か現れる.これはテザ 一に作用する軸方向応力が $\theta_{1}$ の回転を抑制する力と して作用するためだと考えられる.

このことから微小変位の運動においても, 制御下で 剛体と柔軟体の運動が連成する場合には, 結合点にか かる拘束力を正確にモデル化することが必要であるこ とを示している.

5.2 大変形・大変位問題 本節では, 微小重力 下における姿勢制御下における柔軟体・剛体系の平面 運動に対して数值シミュレーションを行い，その運動 のメカニズムについて検討を行う. 柔軟体と剛体の相 互作用を調べるために, 柔軟体の一端を移動させ以下 の場合について比較検郡する.

数值解析に用いたパラメータは前節と同様である. なおここでは减衰は考虑していない，また，要素分割 数は $n=30, \mathrm{~g}=0.98[\mathrm{~m} / \mathrm{s}]$ とし, 数值積分には 4 次の ルンゲクッタ法を用いている.

柔軟体は初期にたわみがない状態で，剛体 1 に角度 1/18[rad] を与えた時の柔軟体・剛体系の初期形状を 図 9 に示す. ここでは，柔軟体上端の水平方向変位 $\varepsilon_{0}=10 \sin 0.3 t$ を与えて往復運動する場合を考える.

図 10 に制御を行わずに柔軟体・剛体系の移動端に

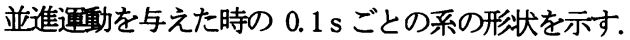
また，図 11 に制御下における柔軟体・剛体系の移動 端に並進運動を与えた時の $0.1 \mathrm{~s}$ ごとの系の形状であ る. 上端の往路の移動中を黒のプロットで示し，復路 の移動中を白のプロットで示した. 図 10 の結果では, まず柔軟体の一端が並進運動することによって柔軟体 と岡体の結合点に拘束力が生じる. そのとき剛体 2 は 大回転を伴った運動を行う. 一方, 図 11 では柔軟体 と剛体の連成運動下においても制御効果か碓認される. 


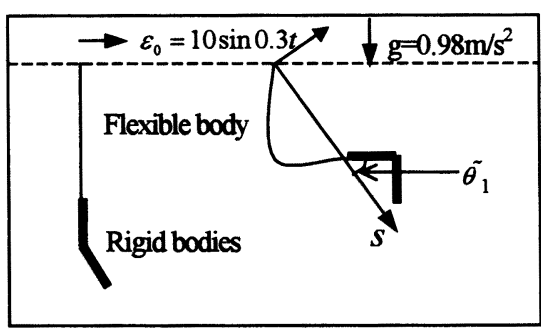

Fig.9 Configuration of the translation of the system

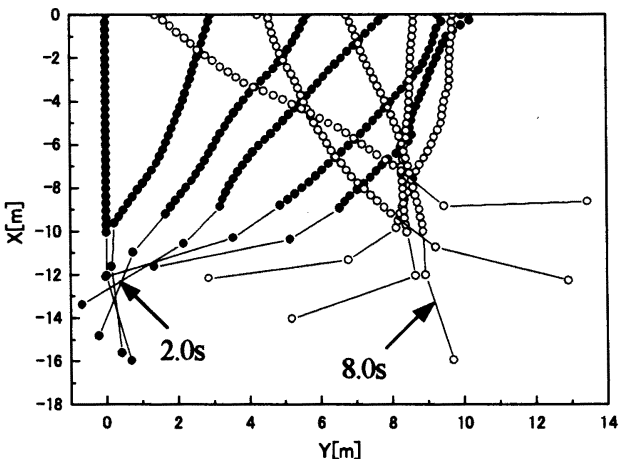

Fig.10 Shape of the system under no-control in the case that the upper end of the flexible body moves horizontally

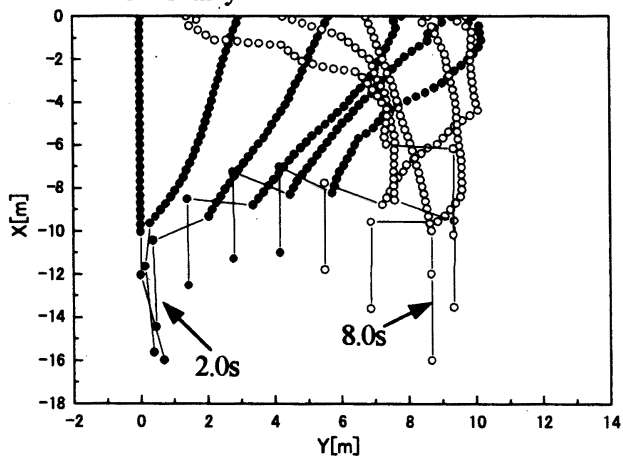

Fig.11 Shape of the system under angular momentum control in the case that the upper end of the flexible body moves horizontally

しかし関節に与えられたトルクが柔軟体に大変形を励 起している様子が碓認される. そこで，制御下の運動 特性を詳細に把握するために制御がない場合の系の運 動の時刻歷を図 12 に, 制御下の系の運動の時刻歷を 図 13 に示す.ここで， $\theta_{2}$ は用体 2 の角度， $\tilde{\theta}_{1}$ は図 9 に示すような用体 1 の角度, $d \phi / d t$ はリアクションホ イールの角速度を示している. $\mathrm{s}$ は図 9 に示すように 柔軟体の縦方向の変形量を表している. 図 12,13 の 比較から制御下の方が横たわみが大きいことがわかる. このことは, 制御下では弦の変形が励起されることを 示している.

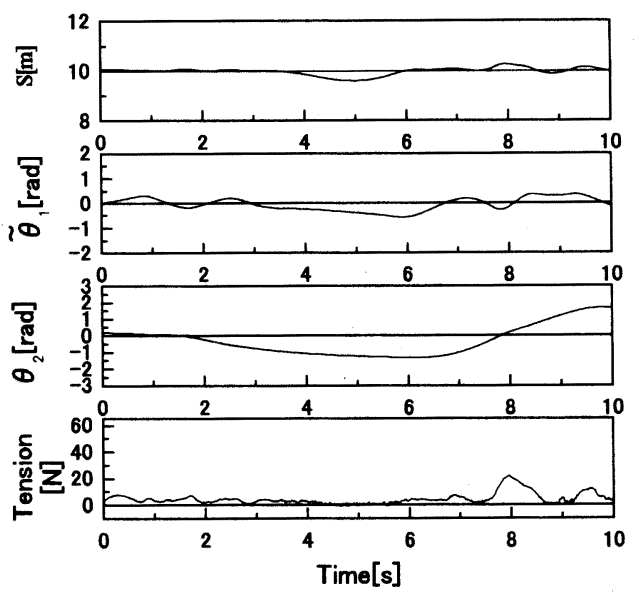

Fig. 12 Time history under no-control
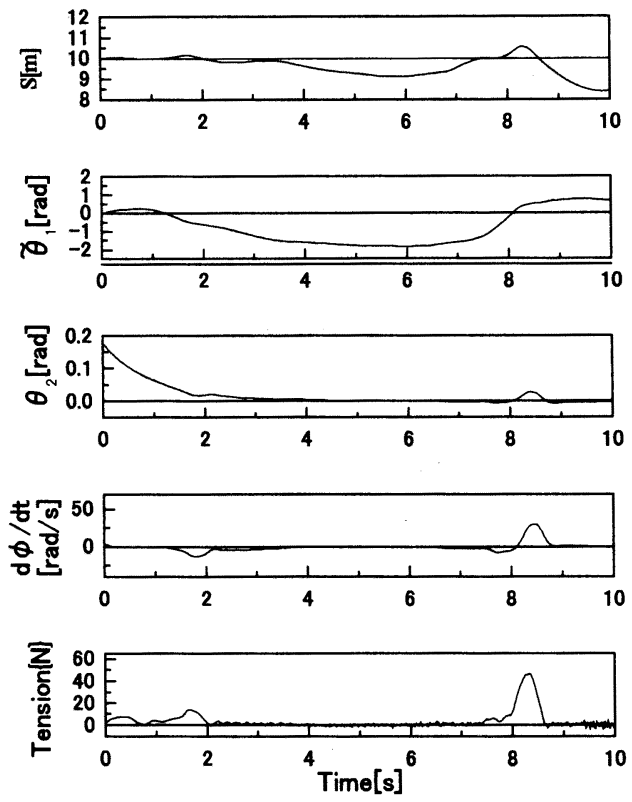

Fig. 13Time history under the angular momentum control

また, 図 13 において 20 s 前と $8.5 \mathrm{~s}$ 後の時刻にお いて角速度の変化が大きい.この時刻においては制御 をしない場合は剛体が大きく振れ回るので制御下にお いては㓮体の回転を抑制するために以下の運動が励起 される. まず, リアクションホイールが回転しその角 運動量が大きくなる. 次にそれを抑制するために関節 トルクが発生しテザーに張力が生じる. これにより剛 体系が上方に移動するので結果として柔軟体に大変形 を生じさせる.

以上のように本報でモデリング，定式化を行った制 御下における大変形，大変位を伴う柔軟体と剛体系の 
連成運動に関するメカニズムの概略を数值解析結果に より示すことができた.

\section{6. 結 論}

本研究では，テザードシステムをテザーと2剛体系 からなる系としてモデル化し，先端岡体の姿勢制御下 におけるテザードシステムの動的応答について主に大 変形, 大変位を伴う場合の系の運動を検討した. この とき，既に提案したリアクションホイール制御，角運 動量抑制制御を適用した.

まず，線形モデルを用いた固有值解析により各制御 手法における制御入力ゲインに対する固有振動特性を 捉えた. 例えば, 制御入力ゲインを大きくした時に振 動モードによって制御効果が向上する，あるいは减少 するという特徴を明らかにした。

次に，固有特性を初期外乱を与えた自由振動に対す る数值解析結果によって確認した. このとき, 線形乇 デルとANC 法を用いたモデルに対する数值解析結果の 比較を行い，本報で扱う柔軟体に連結された岡体系の 姿勢制御下では，微小振動においても結合点に作用す る拘束力を正確にモデル化すること，すなわち軸方向 応力を考慮することの必要性を示した。

さらに, 大変形・大変位問題の例題として, 柔軟体 の一端を並准移動させた場合の数值解析を行った. こ れによると，剛体の姿勢制御を行う際にリアクション ホイールの角運動量が大きくなり，この角運動量を排 出するために与えられた関節トルクが, 柔軟体に大変 形を生じさせる現象が確認された.

\section{文献}

(1) A.K.Misra, Dynamics and Control of Tether Connected TwoBody Systems, Proc. 33rd Congress of the International Astronautical Federation, (1982), 82.

（2）小山孝一郎, Shuttle/Tethered Satelite System (TSS)の紹介 と米国におけるその研究の現状, 東京大学宇宙航空研究所 報告, 16-2(A)，(1980), 935.

（3）海洋調査フロンティア，海洋調查技術学会，(1993), 259.

(4) Y. Terumichi, et al, Nonstationary Vibrations of a String with Time-Varying Length and a Mass-spring System Attached at the Lower Fnd, Nonlinear Dynamics 12, (1997), 39.

(5) S.Kaczmarczyk, and W.Ostachowicz, Non-Stationary Responses of Cables with Slowly Varying Length, J.of Acoustics and Vibration, 5-3(2000), 117.

(6) A.A.Shabana, Non-Linear Dynamics of Multibody System with Generalized and Non-Generalized Coordinates, Virtual Nonlinear Multibody Systems NATOAdvanced Study Institute, II/228

（7）能見公博・他 2 名，弦下端に取り付けられた剛体系の姿勢 制御, 機論 67-664, C(2001-12), 3808 .

(8) A.A.Shabana, et al, Application of the Absolute Nodal Coordinate Formulation to Large Rotation and Large Deformotion Problems , J.of Mechanical Design, 120 (1998), 188.

（9）高橎義考 · 清水信行, Absolute Nodal Coordinate 法による 梁の多体動力学解析に関する研究(有限変位・微小歪とした 時の弾性力の迸出)機論 67-655, C(2001-3), 36 .

（10）竹原昭一郎 - 他 3 名, 弦・䣓体系の運動解析に関寸る研究， 機論 69-678, C(2003-2), 349.

（11）原田裕紀・他 3名, 弦に拘束された岡体系の通動に関する 研究，日本機珹学会 Dynamics and Design Conference 2000 CD·Rom 論文集, (2000), 534.

（12）清水信行，機械振動の解析と計算，才二厶社, (1992),220. 